\title{
The Effect of 'Fish Diversity' Book in Kampar District on the Learning Motivation and Obstacles of Kampar High School Students through Online Learning during the COVID-19 Period
}

\author{
Yustina Yustina $^{1^{*}}$, Lilia Halim ${ }^{2}$, Imam Mahadi ${ }^{1}$ \\ ${ }^{1}$ Universitas Riau, Indonesia \\ ${ }^{2}$ Universiti Kebangsaan Malaysia \\ *Correspondence to: yustina@lecturer.unri.ac.id
}

\begin{abstract}
The study aims to analyze the effect of the fish diversity book in Kampar District on the learning motivation and obstacles of Kampar High School students through online learning during the COVID-19 period. This type of research is a quasi-experimental study with research subjects in class XI SMA Kampar (Kampar High School). In its implementation, students were given a motivational questionnaire in the beginning, after that they were given the task of studying the types of fish in Kampar through the book files of fish diversity in Kampar District through online learning. After online learning, the post-test was given using a questionnaire evaluation of the motivation and online learning obstacles questionnaire. Parameters: learning motivation with five indicators, ten indicators of online obstacles. Motivation data collection using pre-test and post-test. Data is presented and analyzed descriptively. The results obtained an average score of post-test student learning motivation (77.7) increased compared to before studying diversity book (65.9) with an $\mathrm{N}$-gain index of $0.34,74 \%$ of respondents said online learning was more effective, $50 \%$ of respondents stated the ordinary school is better than online learning. This study concluded implementation of fish species diversity books through online learning is effective in increasing student learning motivation, but it is less effective in motivating desires, appreciation, and not being attractive enough. The obstacles of online learning at Kampar High School include internet network facilities and field practicum during the COVID-19 period.
\end{abstract}

Keywords: diversity book; learning; motivation; online obstacles

Recommended citation: Yustina, Y., Halim, L., \& Mahadi, I. (2020). The Effect of 'Fish Diversity' Book in Kampar District on the Learning Motivation and Obstacles of Kampar High School Students through Online Learning during the COVID-19 Period. Journal of Innovation in Educational and Cultural Research, 1(1), 7-14

\section{INTRODUCTION}

Kampar Regency in Riau Province has the potential for freshwater fish diversity. This potential should get the attention of the government and researchers, especially as students and educators for information on local biodiversity in Kampar District, to increase student motivation and concern for the potential of local biodiversity. This locally-based biodiversity enrichment book that has been developed needs to be tested, implemented in the classroom learning process, especially to analyze student motivation. Student learning motivation increases through contextual learning (Yustina \& Febrita, 2013). Contextual learning in class cannot take place because of the COVID-19 pandemic case, which has not been detected when it ends.

Based on government policy in Indonesia, solutions for implementing online learning processes (in the internet network). Severe short-term disruptions are felt by many families around the world for which there is no model to predict the COVID phenomenon (Ivanov, 2020). Schooling at home is not just a big surprise for parents' productivity, social life, and student learning. Furthermore, an understanding of the low COVID-19 pandemic (Fauzi et al., 2020) needs to be considered teaching moving online and replacing traditional exams with online assessment tools (Burgess \& Sievertsen, 2020). Based on the description above, the implementation of learning to analyze the effect of fish species diversity book in Kampar Regency on the motivation to learn from Kampar High School students is conducted online. Learning must be designed with a variety of competencies including mastering ICT (Communication Information Technology) well, to access information, and be able to turn problems into opportunities, have excellent problem-solving skills. Kizilcec and Schneider (2015) interpret various patterns of student behaviour as expressions of different needs that students want to meet by engaging in online learning.

In the 21st century technology has become one of the critical things in the implementation of various activities. The impact of progress in the 21st century also occurs in the field of education, one of which is technology- 
based learning. The progress that occurred in the 21st century is a challenge for teachers as educators, especially in implementing learning by integrating technology (Aini \& Kuncahyono, 2020). Online learning, a sudden change in the learning process of creating learning solutions are not as simple as moving the school system to an online learning environment, not just a technical problem. It is a pedagogical and instructional challenge (CoSN, 2020). Learning must be able to answer the challenges of the 21st century, one of which is information literacy and ICT literacy, so that information literacy and ICT students develop (Kemenristekdikti, 2018; Wijayanti, et al., 2017).

Teaching material developed from the potential that exists at the local level has high contextual value for learning in schools where the local potential is used in learning (Richards, 2019; Pandit, 2019). This finding confirms the importance of characteristic local potential in an area, integrated into learning materials so that learning in schools be contextual. However, a real gap was found because many potential areas are not used as a learning material, such as findings from Zhang, et al. (2020); Morrison, et al. (2020) the creativity of teachers in using local learning resources is still low so that the impact on learning is not interesting in terms of content for students. Findings Chang, et al. (2019) strengthening that learning resources that are theoretical and do not present examples that are familiar to students do not stimulate students' desire to master the concepts.

Based on observations so far, in Kampar district, the implementation of online learning has not been generally realized at the Senior High School (SMA) level. It means it is thought to have not been programmed according to the curriculum, guidelines and technology facilities along with network devices, internet and electricity network connections are often extinguished and is a challenge to the readiness of educators and students in implementing online learning. Therefore it is necessary to study the implementation of online learning during the COVID-19 Kampar district. This study aims to analyze the effect of fish species diversity book on learning motivation and online learning obstacles on high school students in Kampar during the COVID-19 period. The diversity of fish species in this study is the variety of species that exist in the Kampar R (local potential) which are integrated as study material.

\section{METHODS}

This quasi-experimental study was carried out in Kampar High School, Riau Regency, with a purposive sampling technique. The study design was an experimental group pre-test-post-test (Table 1).

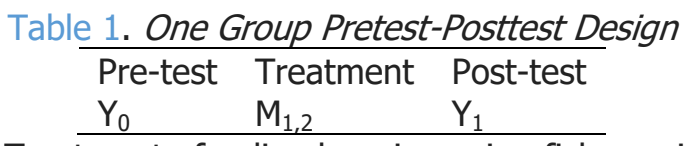

Description: $M_{1,2}$ : Treatment of online learning using fish species diversity book; $\mathrm{Y}_{0}$ : Pre-test before treatment; $\mathrm{Y}_{1}$ : Post-test after treatment

in Kampar and online learning, the dependent variable is motivation and student learning obstacles through online.

\section{Participants}

The respondents are high school students from the area where the data about fish diversity were collected. Those students live around Kampar, so they know the location to be studied. The number of participants was 120 students, with 47 male students and 73 female students. The socio-cultural characteristics of the participants were similar because they were in one area, and most were ethnic Malay, while a small proportion was from other ethnic groups. Participants lived in areas close to schools, so they understood the biodiversity characteristics of living things in the target area of this study. This study takes the target of participants in one region, so it is not influenced by environmental situations that cause differences in existing biodiversity.

\section{Instrument}

The motivation questionnaire sheet compiled in this study is a closed questionnaire sheet with 4 Linkert scales, student learning motivation consists of 5 indicators, namely desires and curiosity, encouragement and learning needs, hopes and ideals, appreciation in learning and exciting activities in learning. The questionnaire file is through Google Form, motivation for evaluation according to Curriculum 2013. The five indicators were developed into some descriptions and then elaborated in 15 statement items, each indicator consisting of 3 statement items. A learning motivation questionnaire was given before and after learning, the questionnaire descriptions in Table 2. 
Table 2. Indicator and Description of Student Learning Motivation Questionnaire

\begin{tabular}{ll}
\hline Indicator & \multicolumn{1}{c}{ Description } \\
\hline Desire and curiosity & Desire and curiosity to learn new information and learning tools. \\
\hline $\begin{array}{l}\text { Encouragement and } \\
\text { learning needs }\end{array}$ & Facilitate educators, need support, feel proud of the results achieved. \\
Future hopes and ideals & $\begin{array}{l}\text { Striving, persevering (learning intensity) and optimistic (confident) completing } \\
\text { tasks, relevant to learning achievement targets. }\end{array}$ \\
$\begin{array}{l}\text { Appreciation in learning } \\
\text { Interesting activities in and informing scores, achievements, opportunities for competition. } \\
\text { learning }\end{array}$ & $\begin{array}{l}\text { Attitudes of educators, and peers towards students, material relevant to a student's } \\
\text { daily life, facilitated in a fun, clear, straightforward, and easily understood manner. }\end{array}$ \\
\hline
\end{tabular}

\section{Data Collection}

This study began by exploring the types of fish in the Kampar River with the identification of fish species. The types of fish identified are then arranged in the form of descriptions or teaching materials. The teaching materials have integrated. The research data were collected with questions in the form of multiple-choice, each of which uses five answer choices. The pretest is done before learning, and the posttest is done after learning. Before the questions were used, a validity test and a reliability test were carried out which had obtained the results of all item questions declared valid because of the value of $r$ arithmetic $\geq r$ table (2-sided test with sig. 0.05). The questions were also stated to be reliable because all items with an alpha value $>0.7$ meant sufficient reliability. After being declared valid and reliable, the questions are used as research data collection instruments. The motivation questionnaire sheet compiled in this study is a closed questionnaire sheet with 4 Linkert scales. The questionnaire file is used to collect data in Google Form.

\section{Data Analysis}

The average score obtained for each aspect of motivation is converted into interval data with a scale of four. The data obtained was changed in the form of a score, then the data in the form of the score will be changed to a score, i.e. the score obtained divided by the maximum score multiplied by a maximum score of 100 (Suwono et al. 2017). The data used are normalized Gain Index and classification/effectiveness to find out the increase in learning motivation (Hake, 1999). The average score of normalized gain (Gain index) is the difference between the average final score (posttest) divided by the difference in the score of the maximum score minus the average score of the initial test (pretest). Google form questionnaire about the obstacles of online learning consists of aspects of advantages, disadvantages, and opportunities for post-COVID-19 online learning. Interpret the normalized gain ( $\mathrm{g}$ ) index and classification (Hake, 1999) Table 3.

Table 3. Normalized Gain Index Scores and Their Classifications
\begin{tabular}{ll}
\hline Normalized Gain Index & Classification \\
\hline$(\mathrm{g}) \geq 0,70$ & High/very effective \\
$0,30 \leq(\mathrm{g}) \geq 0,70$ & Moderate/effective \\
$(\mathrm{g})<0.30$ & Low/less effective \\
\hline
\end{tabular}

This study began by exploring the types of fish in the Kampar River with the identification of fish species. The types of fish identified are then arranged in the form of descriptions or teaching materials. The teaching materials that have integrated with the fish diversity of the exploration results delivered online.

\section{RESULT AND DISCUSSION}

The results of a detailed learning motivation assessment are shown in Table 4.

Table 4. Indicators and scores of pre-test, post-test learning motivation and n-Gain index categories

\begin{tabular}{lllll}
\hline Indicator & \multicolumn{2}{c}{ Min Score } & \multicolumn{2}{c}{ n-Gain Index and category } \\
\hline Motivation to learn & Pre-test & Post-test & n-Gain Index & Category \\
\hline Desire & 60,1 & 72 & 0,29 & Less effective \\
Encouragement & 65,3 & 79.3 & 0,40 & Effective \\
Hopes & 74 & 87.2 & 0,51 & Effective \\
Appreciation & 55 & 68 & 0,29 & Less effective \\
Interesting activities & 75 & 82 & 0,28 & Less effective \\
Average & 65,9 & 77,7 & 0,34 & Effective \\
\hline
\end{tabular}


Based on Table 4, the average score of pre-test motivation and desire of students is 60.1 , and post-test 72 with N-Gain 0.29 (less effective classification) decreases students' desires and desires to learn. The motivation and needs of students from the average score of 65.3 pre-test and post-test increase to 79.3 with N-Gain 0.40 (effective classification) motivate the form of encouragement and student needs through online learning. The average pre-test score of 74 and post-test 87.2 with N-Gain 0.51 (effective classification) increases student hopes and student ideals through the implementation of this learning. The average score of pre-test appreciation in learning obtained by 55 and post-test of 68 with $\mathrm{N}$-Gain 0.29 means that this learning gives the impression that it is less effective in increasing student motivation to get an appreciation in learning. Based on the new score in learning, the achievement was 75, and the post-test increased to 82, with N-Gain 0.28 (less effective classification) increasing the motivation of students in learning.

The obstacles of online learning are in terms of readiness, strengths, weaknesses of online learning, and wisdom COVID-19. The survey shows the lack of preparation for the implementation of online learning, caused as a spontaneous solution to overcome the learning of the COVID-19 phenomenon. Furthermore, respondents from 8 statements lacked online, there were 7 statements chosen from highest to lowest, namely: to study during covid$19(74.7 \%)$, to make it easier to study $(51.2 \%)$, stating there was no excess online lecture $(11.6 \%)$, suitable for this type of practice $(8.8 \%)$, more cost-effective $(5.1 \%)$, can be done in different places $(4.2 \%)$, easy to ask questions $(4 \%)$, and can study no preparation/no bath $(0.5 \%)$.

Lack of online lectures according to the respondents' statement from the most to the lowest of 11 answer choices, there were seven statements chosen by the participants. There were $86 \%$ stated the cost was more expensive, $64.4 \%$ was wasteful because the lecture was not on time, $63.7 \%$ time was limited, $62,8 \%$ needed lots of quotas, $58.6 \%$ had difficulty asking questions, $48.8 \%$ said it was ok, and $1.4 \%$ said there was no shortage and complicated $1.4 \%$, lack of precise network difficult areas and the quality of the bad network with $0.5 \%$ for each.

The wisdom and implementation of online learning after the COVID-19 pandemic (Figure 1a, 1b) as follows.

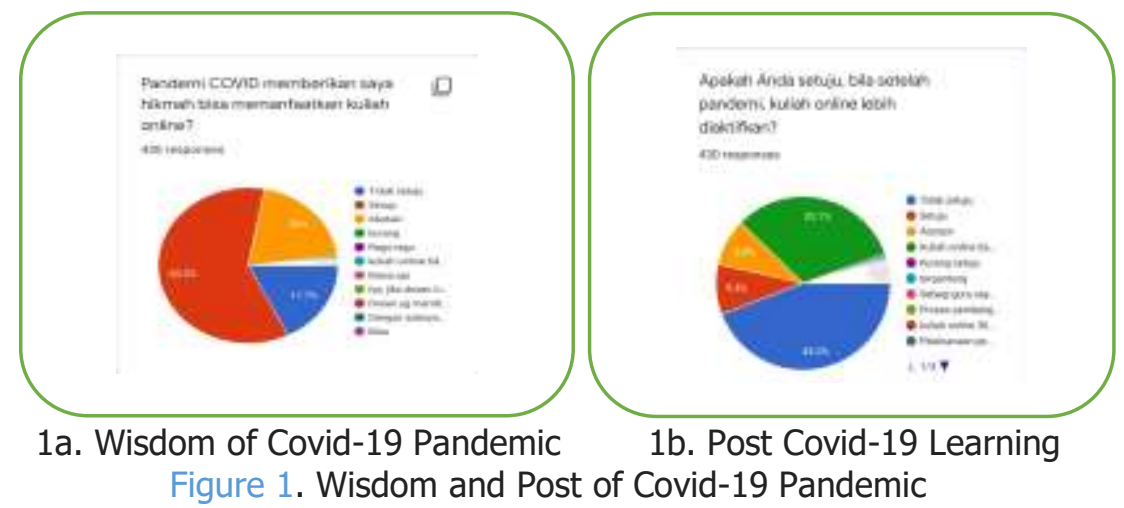

Figure 1a shows that the wisdom of COVID-19 in learning from $97.9 \%$ of 430 people stated $60.2 \%$ agreed to go online, $17.7 \%$ disagreed, and $20 \%$ abstained. Figure $1 \mathrm{~b}$ shows that in the post-COVID-19 pandemic, according to respondents' statements as many as $94.1 \%$ of 430 people stated that after COVID-19 online lectures were more activated, $9.3 \%$ statements agreed, $44.2 \%$ disagreed, $32.1 \%$ online lectures, and $8.8 \%$ abstention.

\section{Student Learning Motivation}

This lack of desire and curiosity of students to learn is because learning is not carried out contextually, there is no direct stimulus from the teacher through challenges with verbal questions, there is no equal opportunity to express ideas, and students' curiosity to learn new information. The availability of learning facilities is not good because not doing field practice. There is no teacher effort through positive encouragement of attitude and verbal inspiration, leading, creative, and pleasant atmosphere. Encouragement of positive verbal attitudes and inspiration from the teacher is the most crucial factor to increase student motivation. Dogan (2015) states that the strongest predictors of academic success include: teachers must provide positive verbal inspiration to support students' academic independence; The teacher must show a positive attitude that helps motivate students, activities that are relevant to cognitive involvement in learning settings. It academically will be able to motivate students to learn. The learning source used is contextual so it is a fact that students are interested in the description of the fish diversity contents that the object of study is around their life.

The encouragement of learning from students because it requires information on the diversity of fish species as a local wealth of the student's local area, curiosity about the richness of fish species from the student area, getting to know the types of fish in students' daily lives and being affordable with their fundamental knowledge 
and easily recognized in their daily lives. Following the needs and feelings of pride in local wealth, as the pride of the potential wealth of fish in the region, useful in fish farming, and as a source of animal protein. Increased motivation to learn because there is a need and drive to be fulfilled (Yustina et al., 2013, 2015).

Students hope that the information obtained can be utilized in life as information enrichment. Students follow the information book on the diversity of fish species in Kampar and reflect on the fundamental knowledge they have in the learning process and are optimistic in completing assignments because this activity is relevant to students' daily experiences, needs, and achievements. Improving student motivation is an alternative form of positive impact from a more comprehensive learning model (Rahardjanto et al., 2019; Law et al., 2019).

This learning lacks the opportunity for students to participate contextually, there are burdens, and results obtained by students without being informed, and there is no direct praise by the teacher either individually or in groups. Hence, students learn individually without competition to get praise from other groups and the teacher. Learning motivation also plays an important role directly affecting learning performance in learning settings. The presence of a teaching teacher was found to have a direct positive impact on cognitive presence and social presence (Sari \& Sugiyarto, 2015). Kim and Frick (2011) state that students are more likely to be motivated when they solve real-world problems or perform authentic assignments (problem-centred principles) and when they can incorporate what they have learned into their lives (the principle of integration).

This learning is facilitated less pleasantly and must be understood independently. This learning presents questions and practice questions, but is less enjoyable because of the teacher's stimulus comments, students participate from themselves and saturate in processing information, without collaborative learning (Sari \& Sugiyarto, 2015). Barak et al. (2016) suggest that online forums are the preferred method of communication and that involvement in interactions has a significant impact on motivation.

From the description above, as a whole, the implementation of the learning book for fish diversity in Kampar obtained an average pre-test score of 65.9 , and the post-test increased to 82, with N-Gain 0.34 (effective classification) increasing the motivation to learn the diversity of fish species in Kampar Regency. Details are effective in increasing motivation and encouragement, but less effective in increasing desire, less effective at appreciation, and less effective at attracting learning activities. The learning environment is not contextual, does not involve the teacher's role directly, and causes a lack of learning attractiveness. Horzum, et al. (2015) reported that there was no significant relationship between motivation and student achievement through online learning. Croxton (2014) explains the lack of active interaction with teachers and fellow students through online learning. Students can feel less motivated to learn.

\section{Obstacles of Online Learning}

Sun and Chen (2016) suggest that active online learning depends on 1) curriculum design about content, instructor and student interaction, 2) creating a sense of online learning community, 3) rapid technological advancements such as device fascism computers, internet network servers, support effective strategies for success in online teaching transitions. According to the results of Wasim et al. (2014) research, that the assumptions of institutions, curriculum, facilities, instructors, communities, access. Procurement of network facilities, software, computers, free internet in learning, fast and quality network speed facilities so that there are not many distractions. Fauzi et al. (2020) added that it is necessary to consider the literacy competencies of students in online teaching.

Online learning readiness generally consists of: a) assumptions, namely vision, mission and support from institutions or institutions; b) curriculum, and elaborated on the e-learning or web-based learning syllabus, focused and measured material content, the accuracy of online teaching strategies and teacher and student guides and supported by the learning design and instructor's guide; c) facilities, including the availability of computers, internet networks/webs, and ICT literacy competencies; d) human resources such as instructors, training and mentoring and online learning communities that involve influences for shared needs, membership, and emotional links; and e), access, related to information and communication technology (ICT) capabilities, virtual learning, content and online pedagogical learning. In addition to online learning readiness, challenges are also encountered. In this research, online learning is conducted. Although learning resources are interesting, there are still many obstacles to online activities. Practicum as a series of activities that should not be separated cannot be done, this is the main obstacle in this research. The online learning cannot replace lab activities in the laboratory.

The challenges of e-learning include 1. Learning styles and culture, 2. e-learning pedagogy, 3. Technology. Institutions have a variety of applications and computer operating systems, 4 . Technical training, and 5 . Time management. E-learning is $30 \%$ more time consuming for academics than traditional classroom teaching relating to the creation of a process to develop students' practical skills (Abdulhak, et al., 2018; Babu \& Sridevi, 2018), but online learning has advantages and disadvantages (Figure 2) and gave wisdom during the COVID-19 period. 


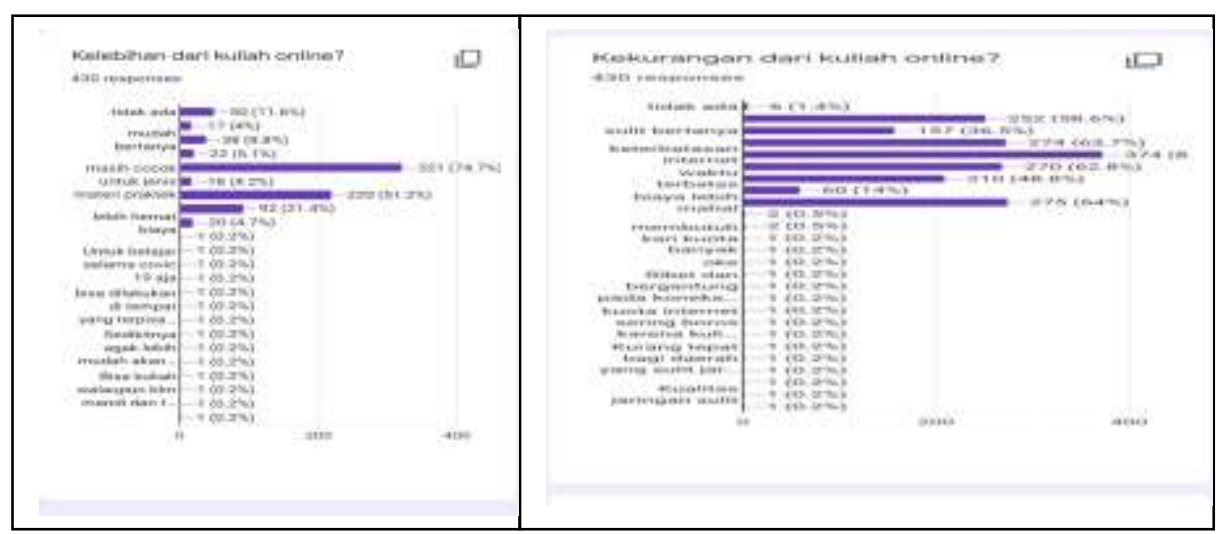

2a. Advantages of Online Lecture $2 b$. Disadvantages of Online Lecture Figure 2. Advantages and Disadvantages of Online Lecture

Furthermore, Arkorful (2014); Babu and Sridevi (2018) add the advantages of E-learning. Arkorful (2014), Alsulimani, et al. (2018), Talebian, et al. (2014) stated the disadvantages of e-learning as presented in Figure 2. Vanslambrouck et al. (2018) state that online learning creates barriers to persistence, such as unexpected workloads that lead to tonight and family work problems, cost-score balance, practical relevance. The wisdom and activation of post-COVID-19 online lectures, as much as $97.9 \%$, it can be concluded that COVID-19 tends to give wisdom to online lectures and is activated in the online form, facilitating the widespread of website use and the development of online community groups supported by Web Pages and various forms of communication software (Sun \& Chen, 2016).

\section{CONCLUSION}

The implementation of the fish diversity book through online learning is effective in increasing student motivation, but it is less effective in motivating desires, appreciation, and not being attractive. The obstacles of online learning at SMA in Kampar include internet network facilities and field practicum that are not implemented. The obstacles of online learning are that practicum activities cannot be replaced online, costs, and internet network facilities. Respondents stated that ordinary schools are better than online learning, and it can be stated that the COVID-19 pandemic period brought the wisdom of implementing online lectures. Schools need the readiness to create a web-based curriculum, prepare computer equipment, online networking, management, online virtual learning media, streamlined and quality internet connectivity without pay, gather instructor communication, and online learning communities.

\section{REFERENCES}

Abdulhak, I., Djohar, A., \& Wahyudin, D. (2018). The Development of Hybrid Learning Curriculum Model for Improving Teachers Competencies in Teacher Education Institutions in Indonesia and South Korea. International Research Journal of Advanced Engineering and Science, 3(1), 31-35.

Aini, D. F. N., \& Kuncahyono. (2020). Pengembangan Pedoman E-Modul Berorientasi Student Active Learning Sebagai Pendukung Pembelajaran di Sekolah Dasar. Jurnal Pendidikan Dasar Nusantara, 5(2), 292-304.

Alsulimani, T., \& Kaabi, H. (2018). The effect of E-Learning on Teachers' Motivation: a case study in Jeddah University. International Journal of Management and Information Technology, 14(1), 3316-3327.

Arkorful. (2014). The role of e-learning, the advantages and disadvantages of its adoption in Higher Education. International Journal of Education and Research, 2(12), 397-410.

Babu, G. S., \& Sridevi, K. (2018). Importance of E-Learning in Higher Education: a Study. International Journal of Research Culture Society. 2(5), 1-8.

Barak, M., Watted, A., \& Haick, H. (2016). Motivation to learn in massive open online courses: Examining aspects of language and social engagement. Computers \& Education, 94, 49-60. 
Burgess, S., \& Sievertsen, H. H. (2020). Schools, skills, and learning: The impact of COVID-19 on education. VoxEu. org, 1.

Chang, C. Y., Kao, C. H., Hwang, G. J., \& Lin, F. H. (2019). From experiencing to critical thinking: a contextual game-based learning approach to improving nursing students' performance in Electrocardiogram training. Educational Technology Research and Development, 12(1), 1225-1245.

CoSN (Consortium for School Networking) member exclusive resource. (2020). COVID-19 Response: Preparing to Take School Online. It has been made available to the edtech community as a courtesy. @ 2020 CoSN (Consortium for School Networking). All rights reserved.

Croxton, R. A. (2014). The role of interactivity in student satisfaction and persistence in online learning. Journal of Online Learning and Teaching, 10(2), 314.

Dogan, U. (2015). Student engagement, academic self-efficacy, and academic motivation as predictors of academic performance. The Anthropologist, 20(3), 553-561.

Fauzi, A., Husamah, H., Miharja, F. J., Fatmawati, D., Permana, T. I., \& Hudha, A. M. (2020). Exploring COVID-19 Literacy Level among Biology Teacher Candidates. Eurasia Journal of Mathematics, Science and Technology Education, 16(7), 1864.

Hake, R. R. (1999). Analyzing change/gain scores. Unpublished.[online] URL: http://www. physics. indiana. edu/ sdi/AnalyzingChange-Gain. pdf.

Horzum, M. B., Kaymak, Z. D. \& Gungoren, O. C. (2015). Structural equation modeling towards online learning readiness, academic motivations, and perceived learning. Educational Sciences: Theory \& Practice, 15(3), 759-770.

Ivanov, D. (2020). Predicting the impacts of epidemic outbreaks on global supply chains: A simulation-based analysis on the coronavirus outbreak (COVID-19/SARS-CoV-2) case. Transportation Research Part E: Logistics and Transportation Review, 136, 101922.

Kemenristekdikti. (2018). Pengembangan IPTEK dan Pendidikan Tinggi di Era Revolusi Industri 4.o. Retrieved from https://www.ristekdikti.go.id/pengembangan iptek-dan-pendidikan- tinggi-di-era-revolusi-industri4-0.

Kim, K. J., \& Frick, T. W. (2011). Changes in student motivation during online learning. Journal of Educational Computing Research, 44(1), 1-23.

Kizilcec, R. F., \& Schneider, E. (2015). Motivation as a lens to understand online learners: Toward data-driven design with the OLEI scale. ACM Transactions on Computer-Human Interaction (TOCHI), 22(2), 1-24.

Law, K. M., Geng, S., \& Li, T. (2019). Student enrollment, motivation and learning performance in a blended learning environment: The mediating effects of social, teaching, and cognitive presence. Computers \& Education, 136, 1-12.

Morrison, J., Frost, J., Gotch, C., McDuffie, A. R., Austin, B., \& French, B. (2020). Teachers' Role in Students' Learning at a Project-Based STEM High School: Implications for Teacher Education. International Journal of Science and Mathematics Education, 1-21.

Pandit, G. L. (2019). Children's education, institutions of learning, technology and wisdom inquiry: Global challenges and methodological perspectives. Philosophia, 1-29.

Rahardjanto, A., Husamah, \& Fauzi, A. (2019). Hybrid-PjBL: Learning Outcomes, Creative Thinking Skills, and Learning Motivation of Preservice Teacher. International Journal of Instruction, 12(2), 179-192.

Richards, C. (2019). Later Life Learning From Experience: The Cross-cultural Importance of 'Life Reviews' in Seniors' Lifelong Education and Learning. Zeitschrift für Weiterbildungsforschung, 42(1), 5-22.

Sari, D. S., \& Sugiyarto, K. H. (2015). Pengembangan multimedia berbasis masalah untuk meningkatkan motivasi belajar dan kemampuan berpikir kritis siswa. Jurnal Inovasi Pendidikan IPA, 1(2), 153-166. 
Sun, A., \& Chen, X. (2016). Online education and its effective practice: A research review. Journal of Information Technology Education, 15, 157-190.

Suwono, H., Pratiwi, H. E., Susanto, H., \& Susilo, H. (2017). Enhancement of students' biological literacy and critical thinking of biology through socio-biological case-based learning. Jurnal Pendidikan IPA Indonesia, 6(2), 213-220.

Talebian, S., Mohammadi, H. M., \& Rezvanfar, A. (2014). Information and communication technology (ICT) in higher education: advantages, disadvantages, conveniences and limitations of applying e-learning to agricultural students in Iran. Procedia-Social and Behavioral Sciences, 152, 300-305.

Vanslambrouck, S., Zhu, C., Lombaerts, K., Philipsen, B., \& Tondeur, J. (2018). Students' motivation and subjective task value of participating in online and blended learning environments. The Internet and Higher Education, 36, 33-40.

Wasim, J., Sharma, S. K., Khan, I. A., \& Siddiqui, J. (2014). Web based learning. International Journal of Computer Science and Information Technologies, 5(1), 446-449.

Wijayanti, W., Maharta, N., \& Suana, W. (2017). Pengembangan perangkat blended learning berbasis learning management system pada materi listrik dinamis. Jurnal Ilmiah Pendidikan Fisika Al-Biruni, 6(1), 1-12.

Yustina \& Febrita, E. (2013). Increase Motivation and Knowledge the Environment through Contextual Model. Asian Social Science, 9(12), 237.

Yustina \& Suwondo. (2015). Sikap ilmiah dan kreativitas produk pada isu lingkungan melalui pembelajaran berbasiskan proyek. Bioedukasi: Jurnal Pendidikan Biologi, 8(2), 48-52.

Zhang, W., Wang, Y., Yang, L., \& Wang, C. (2020). Suspending classes without stopping learning: China's education emergency management policy in the COVID-19 Outbreak. Journal of Risk and Financial Management, 13(55), 2-6. 